\title{
PENGARUH PROBIOTIK FMPLUS TERHADAP RECAHAN KARKAS DAN LEMAK ABDOMINAL BROILER FASE FINISHER
}

\author{
Helda $^{1)}$ dan Catootjie L.Nalle ${ }^{1)}$ \\ 1) Jurusan Peternakan, Politeknik Pertanian Negeri Kupang, \\ J. Prof. Dr. Herman Yohanes Lasiana Kupang P.O.Box. 1152, Kupang 85011 \\ Korespondensi: heldasyarif@gmail.com
}

\begin{abstract}
The aim of this research was to evaluate the effect of Probio FMplus on carcass component parts and abdominal fat of growing broilers. A total of 150 day-old broiler chicks (unsexed, Cobbs strain) were used in the present study. The chicks were randomly distributed to 25 pens (6 birds/pen). The experiment was design by using a complete randomized design consisting of five treatments and five replications. The treatments were a control diet without the addition of probio FMplus in drinking water (RO), control diets added with $0.5 \%$ Probio FMplus (R1), control diets added with 1.0\% Probio FMplus (R3), and control diets added with 2.0\% Probio FMplus (R4). The variables measured were carcass component parts and abdominal fat percentage. The result showed that the treatments did not have any significant effects $(P>0.5)$ on all parameters measured. However, numerically it seemed that the breast meat and thigh percentages of group of birds fed diets added with Probio FMplus were higher than those of control diets without Probio FMplus. In conclusion, the addition of Probio FMplus (O to 2\%) did not give any beneficial effects of carcass component parts and abdominal fat percentages. Further research is needed to evaluate the higher level of Probio FMplus.
\end{abstract}

Keywords: Abdominal fat, Broiler, Carcass, Symbiotic.

\section{PENDAHULUAN}

Populasi penduduk Indonesia saat ini berkembang sangat pesat, sehingga mengakibatkan peningkatan kebutuhan pangan. Akibatnya industri pertanian dituntut untuk berproduksi secara maksimal untuk memenuhi kebutuhan masyarakat. Hal tersebut juga dirasakan oleh industri subsektor peternakan khususnya industri ungags sebagai salah satu penyedia sumber protein asal hewani bagi konsumen. Konsumsi daging ayam ras per kapita/tahun masyarakat Indonesia pada 2017 sebesar 5,68 kg per kapita/tahun meningkat 573 gram $(11,2 \%)$ dibanding konsumsi tahun sebelumnya. Sedangkan produksi daging ayam pada tahun 2017 3.175.853 ton meningkat 3.495,090,91 Ton tahun 2019 (BPS 2009-2019, Indonesia). Adopsi teknologi di bidang peternakan sangat dibutuhkan untuk mendukung produksi yang maksimal dan berkelanjutan, dengan memperhatikan keamanan produk yang dihasilkan. Penggunaan bahan aditif dalam pakan ternak sejak dahulu telah dilakukan untuk merangsang pertumbuhan dan mencegah penyakit. Menurut Budiansyah (2004), pemberian 
feed aditive tersebut dilakukan untuk memperbaiki performance atau penampilan produksi dari ternak unggas, berbagai macam jenis feed aditive yang telah digunakan sejak dahulu antara lain adalah obat-obatan, antibiotika atau hormon-hormon pertumbuhan.

Awal tahun 2006 penggunaan antibiotik dilarang oleh Uni Eropa sebagai pencegah penyakit (disease prophylactic) atau dikenal pemicu pertumbuhan (Antimicrobial Growth Promoters) di dalam pakan ternak karena meninggalkan residu (Ahmad, 2006)

Beberapa bahan alternatif yang dapat mengganti fungsi dari antibiotik dalam pakan adalah probiotik dan prebiotik. Prebiotik didefiniskan sebagai bahan pakan yang tidak tercerna dan memberikan pengaruh positif pada inang (host),dengan memacu pertumbuhan atau aktivitas bakteri di dalam colon (Choudhari et. al., 2008). Adanya prebiotik yang diberikan melalui pakan, sehingga bakteri yang menguntungkan (apatogen) dalam saluran cerna dapat meningkat dalam menekan bakteri patogen. Cavaazoni $d k k$ (1998) melaporkan probiotik Bacillus coagulans dapat mempertinggi laju pertumbuhan ayam pedaging. Probio FMplus merupakan probiotik yang mengandung Bakteri asam Laktat dengan jumlah $36,1 \times 10^{11}-210 \times 10^{11} \mathrm{cfu} / \mathrm{ml}$ dengan $\mathrm{pH}$ antara 3-3,40. Probiotik ini diproduksi di Politeknik Pertanian Negeri Kupang yang merupakan hasil kerja sama antara Politeknik Pertanian Negeri Kupang dengan Universitas Jambi, namun efektivitas dari simbiotik ini sampai saat ini masih terus diujicoba pada ternak seperti halnya penelitian ini pada ayam broiler. Tujuan dari penelitian untuk mengkaji pengaruh penambahan simbiotik probio $F M^{\text {Plus }}$ terhadap recahan karkas komersial dan lemak abdominal ayam broiler .

\section{METODE PENELITIAN}

\section{Lokasi dan Waktu Penelitian}

Penelitian dilaksanakan di kandang ayam Politeknik Pertanian Negeri Kupang selama 8 minggu dan Laboratorium Teknologi Pakan Ternak

\section{Jenis dan sumber data}

Data dari hasil penelitian yang dilakukan pada Ayam broiler Strain Cobbs berjumlah 150 ekor unsex, Variabel yang Diamati : 1)Persentase recahan karkas ( dada, paha atas,paha bawah), 2 )lemak abdominal 


\section{Metode pengumpulan data}

Metode yang akan digunakan dalam penelitian ini adalah metode Rancangan Acak Lengkap (RAL) dengan 5 perlakuan adalah:

$$
\begin{aligned}
& \text { R0 }=\text { Pakan Komersial + Tanpa Probio FMplus } \\
& \text { R1 }=\text { Pakan Komersial + Probio FMplus 0,5 \% dalam air minum } \\
& \text { R2 }=\text { Pakan Komersial + Probio FMplus } 1 \% \text { dalam air minum } \\
& \text { R3 }=\text { Pakan Komersial + Probio FMplus } 1,5 \% \text { dalam air minum } \\
& \text { R4 }=\text { Pakan Komersial + Probio FMplus } 2 \% \text { dalam air minum }
\end{aligned}
$$

\section{Variebel dan Metode Pengukuran}

Variabel yang diamati dalam penelitian ini adalah:

1. Persentase Recahan Karkas

Recahan karkas yang menjadi variabel dalam penelitian adalah dada, paha atas dan paha bawah. Dada dipisahkan pada ujung scapula dan dorsal rusuk. Paha bagian atas adalah bagian karkas yang dipotong dari perbatasan persendian paha (femur), sedangkan paha bagian bawah dipotong dari batas persendian tulang kering (tibia). Persentase recahan karkas dihasilkan dari perbandingan bobot recahan karkas dengan bobot karkas kemudian dikalikan seratus persen.

Persentase recahan karkas dihitung dengan rumus :

\section{$\frac{\text { Bobot Recahan Karkas }}{\text { Bobot Karkas }} \times 100 \%$}

2. Persentase Lemak Abdominal

Pengukuran lemak abdominal dilakukan dengan mengumpul lemak yang terletak diantara proventiculus, gizzard, duodenum dan disekitar kloaka. Persentase lemak abdomen diperoleh dengan membandingkan bobot lemak abdomen dengan bobot hidup dikalikan 100 (Witantra, 2011).

Persentase lemak abdominal dihitung dengan rumus :

$$
\frac{\text { Bobot Lemak Abdominal }}{\text { Bobot Hidup }} \times 100 \%
$$




\section{Analisis Data}

Data yang diperoleh dianalisis dengan sidik ragam dan untuk menguji perbedaan antar perlakuan dilakukan dengan menggunakan Uji Jarak Berganda Duncan (Gasperzt, 1991).

\section{HASIL DAN PEMBAHASAN}

\section{Persentase recahan karkas}

Recahan karkas merupakan bagian dari karkas yang biasa dipasarkan secara terpisah, seperti bagian dada, paha atas dan paha bawah tertera pada Tabel 1.

Tabel 1. Rataan persentase recahan karkas ayam broiler umur 6 minggu \%

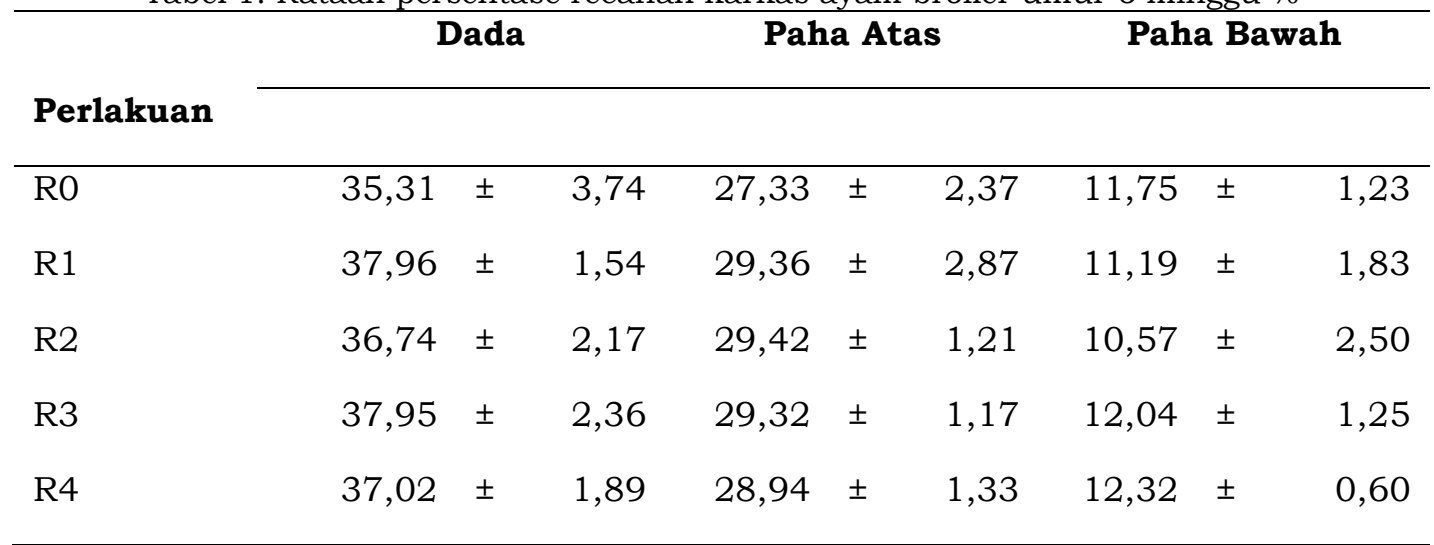

\section{Persentase dada Ayam Broiler}

Hasil analisis ragam menunjukkan bahwa perlakuan berpengaruh tidak nyata $(\mathrm{P}>0,05)$ terhadap persentase dada ayam broiler. Secara numerik persentase karkas dada tertinggi terdapat pada R1 yang diberi penambahan 0,5\% probiotik dalam 1 liter air diikuti dengan R3, R2, R4 dan R0 . Dari hasil penelitian ini dapat dilihat bahwa perlakuan yang mendapatkan penambahan probiotik dalam air minum lebih tinggi dari pada tanpa penambahan probiotik. Hal ini diduga karena probiotik memiliki mikroorganisme hidup yang mempunyai efek positif bagi ternak yang mengonsumsi. Penambahan probiotik dalam air minum mampu menekan perkembangan bakteri patogen baik yang terdapat pada saluran dan probiotik juga berfungsi menjaga keseimbangan ekosistem mikroflora dalam saluran pecernaan dan menyediakan enzim yang mampu mencerna serat kasar, protein, lemak dan mendetosikasi zat racun atau metabolitanya (soeharsono, 1999). Sehingga hasil dari penambahan probiotik dalam air minum mampu menghasilkan pertumbuhan yang baik dan apa bila pertumbuhan ayam broiler yang baik akan menghasilkan 
bobot karkas utuh yang cukup tinggi sehingga persentase karkas dada ayam broiler yang cukup tinggi pula.

Hal ini didukung oleh pendapat Jull (1979) yang mengatakan bahwa semakin besar bobot badan semakin besar pula produksi daging yang dihasilkan. Dijelaskan lebih lanjut oleh (Lesson dan Summers, 1990) bahwa recahan karkas dada merupakan komponen utama dari unggas dan secara kuantatif lebih berat bila dibandingkan dengan bagian sayap, punggung dan paha. Rata-rata persentase bobot dada tiap perlakuan berkisar antara 35,31\%--37,96\%. Persentase dada pada penelitian ini lebih tinggi jika dibandingkan dengan penelitian Fitriawaty, (2011) bahwa persentase karkas dada berkisar antara 32,26-34,09\%.

\section{Persentase Recahan Paha Atas Ayam Broiler}

Hasil analisis ragam menunjukkan bahwa perlakuan berpengaruh tidak nyata $(P>0,05)$ terhadap persentase paha atas ayam broiler. persentase paha atas tertinggi terdapat pada (R2) penambahan probiotik dalam 1 liter air minum diikuti dengan, (R4) penambahan probiotik dalam liter air minum $2 \%$ diikuti dengan (R3) yang diberi $1.5 \%$ penambahan probiotik dalam1 air, (R0) tanpa penambahan probiotik dalam air minum. Dan (R1) penambahan probiotik $0.5 \%$ dalam 1 liter air Persentase karkas paha atas pada ayam broiler umur 6 minggu berpengaruh tidak nyata $(\mathrm{P}>0,05)$ terhadap Persentase karkas paha atas, persentase karkas paha atas paling tinggi diperoleh pada R2 $(29,42 \%)$ dan yang paling rendah adalah R1 $(27,33 \%)$. Terlihat bahwa semakin tinggi level penambahan probiotik dalam 1 liter air semakin tinggi pula persentase paha atas ayam broiler.

Rata-rata persentase berat paha atas tiap perlakuan berkisar antara 27,33-29,42 \%. Dari hasil rata-rata Persentase paha atas pada penelitian selama 6 minggu lebih tinggi jika dibandingkan dengan penelitian Tofari, (2006) yaitu berkisar antara $18,11 \%-28,35 \%$.

\section{Persentase Paha Bawah Ayam Broiler}

Hasil analisis ragam menunjukkan bahwa perlakuan terhadap persentase karkas paha bawah berpengaruh tidak nyata $(\mathrm{P}>0,05)$ terhadap persentase karkas paha bawah Rata-rata persentase karkas paha bawah ayam broiler hasil penelitian selama 6 minggu dari R0, R1, R2, R3 dan R4 yaitu masing- masing R0 $(11,75)$, R1 $(11,19)$, R2 $(10,57)$, R3 $(12,04)$ dan R4 $(12,32)$ Nilai persentase karkas paha bawah tiap perlakuan berkisar antara 10,57-12,32 \% rata-rata persentase karkas paha bawah hasil penelitian selama 6 minggu berada di kisaran angka dari 
penelitian Nurcholis (2016) yang menggunakan Probiotik EM4 melaporkan bahwa rata-rata persentase recahan karkas paha bawah berkisar antara 10,97\%$15,21 \%$.

\section{Lemak abdominal Ayam Broiler}

Lemak abdominal adalah lemak yang terletak diantara proventiculus, gizzard, duodenum dan disekitar kloaka. Persentase lemak abdomen diperoleh dengan membandingkan bobot lemak abdomen dengan bobot hidup dikalikan 100 (Witantra, 2011).Data lemak abdominal diperoleh dari keseluruhan bobot lemak abdominal yang diambil pada daerah abdominal atau daerah bagian dalam rongga perut. Rataan bobot lemak abdominal ayam broiler umur 6 minggu selama penelitian tertera pada Tabel 2.

Tabel 2. Rataan Persentase bobot Lemak Abdominal Ayam Broiler Umur 6 Minggu

\begin{tabular}{cccccccccc}
\hline \multirow{2}{*}{ Perlakuan } & \multicolumn{3}{c}{ Ulangan } & \multicolumn{1}{c}{ Total } & Rataan & SD \\
\cline { 2 - 7 } & 1 & 2 & 3 & 4 & 5 & & & \\
\hline R0 & 1,69 & 1,83 & 1,54 & 1,90 & 1,67 & 8,62 & 1,72 & \pm & 0,14 \\
R1 & 1,23 & 1,34 & 1,55 & 1,43 & 1,82 & 7,38 & 1,48 & \pm & 0,23 \\
R2 & 1,15 & 1,63 & 1,28 & 1,67 & 1,62 & 7,35 & 1,47 & \pm & 0,24 \\
R3 & 1,28 & 1,52 & 0,73 & 1,56 & 1,57 & 6,67 & 1,33 & \pm & 0,36 \\
R4 & 1,81 & 1,69 & 1,57 & 1,41 & 1,64 & 8,13 & 1,43 & \pm & 0,15 \\
\hline
\end{tabular}

Tabel pemberian probiotik pada level 0,5\% sampai level 1,5\% menunjukan bahwa semakin tinggi level penambahan probiotik dalam air minum semakin rendah persentase lemak abdominal ayam broiler sampai pada level 1,5\%. Dari hasil analisa ragam diketahui bahwa pengaruh penggunaan probiotik dalam air minum terhadap bobot lemak abdomen berpengaruh tidak nyata $(P>0,05)$. Data tabel memperlihatkan ada perbedaan antara perlakuan R0 dengan keempat perlakuan lain atau ada perbedaan kadar lemak abdominal pada ternak ayam yang tidak diberi probiotik dengan yang diberi probiotik. Berdasarkan data secara numerik penggunaan probiotik dalam air minum maksimal 1,5\% dapat menurunkan kadar lemak sebesar 22,67\%. Jaelani et,al (2014) melaporkan bahwa penggunaan starbio sampai level 4,5\% dapat menurunkan lemak abdominal sebanyak 29,36\% . Perbedaan ini disebabkan karena perbedaan jenis atau strain bakteri dalam probiotik yang digunakan, dosis pemberian pada ternak,tingkat ketahanan bakteri terhadap kondisi yang ekstrim baik dalam saluran peencernaan 
ternak maupun lingkungan penyimpanan, Menurut Sudha (2011) mengemukakan bahwa probiotik dapat menghasilkan enzim lipase yang bisa memecah lemak bermolekul besar menjadi substrat yang lebih kecil sehingga mudah dicerna dan diserap dalam sistem pencernaan.

\section{SIMPULAN DAN SARAN}

\section{Simpulan}

Pemberian probio FMplus dari level 0,5\%-2\% tidak memberikan pengaruh secara signifikan terhadap persentasi recahan karkas dan persentasi lemak abdominal, namun ada perubahan yang positif dengan penggunaan probio FMplus dalam air minum

\section{Saran}

Berdasarkan hasil penelitian ini disarankan melakukan penelitian dengan pemberian level probio FMplus yang lebih tinggi.

\section{DAFTAR PUSTAKA}

Afriani, H, 2002. Pengaruh Dosis Kultur Bacillus Spp dan Saccharomyces Cerevisiae Sebagai Probiotik Terhadap Performan, Kadar Lemak Dan Kolesterol Ayam Broiler. Tesis. Program Pascasarjana Universitas Pajajaran, Bandung.

Ahmad, I., 2006. Effect Of Probiotic On Broilers Performance. International Journal Of Poultry Science 5 (6): 593-597.

Asriani. 2009. Pengaruh Penambahan Ragi Tape Sebagai Sumber Probitik Dalam Ransum Terhadap Persentase berat bagian-bagian Karkas dan Income Over, Feed and Chick Costa Broiler Fase Finisher. Skripsi. Fakultas Peternakan Universitas Hasanuddin. Makasar.

Badan Pusat Statistik (BPS) Kabupaten Kupang. 2016. Kabupaten Kupang dalam Angka 2016.

Badan Pusat Statistik Indonesia 2009-2019. Produksi dagaing ayam broilerBPS ttps://www.bps.go.id/linkTableDinamis/view/id/1064

Budiansyah, A. 2004. Pemanfaatan probiotika dalam peningkatan penampilan produksi ternak unggas http://www.rudyct.com./PPS702-Ipb/09145/Agus_budiansyah.pdf.

Cavazzoni, V., A.Adami and C. Castrovilli, 1998. Performance of broiler

Fitriawati. 2011. Pengaruh Penambahan Tepung Daun Katuk (Sauropusandrogynius) dan Rimpang Kunyit (curcuma domestika) 
dalam Ransum Terhadap Persentase Bagian-bagian Karkas dan Organ Dalam pada Broiler.Skripsi Universitas Hasanuddin. Makassar.

Gaspersz, V. 1991. Teknik Analisis dalam penelitian percobaan. penerbit Tarsito. Bandung

Gomez, K. A. dan A. A. Gomez. 1995. Prosedur Statistik Untuk Penelitian Pertanian. Edisi kedua.Universitas Indonesia Press. Jakarta. 8-20.

Jaelani A, Gunawan A, Syaifuddin S.The effect of Added Probiotic Starbio on Ration to Slaughtered weight, Dressed Percentage and Abdominal Lipid percentage of Broiler Chicken. Journal Ziraa"ah Volume 39 Nomor 2, Juni 2014 Halaman 85-94 E-ISSN 2355-3545.

Jull, M. A. 1979. Poultry Husbandry. Tata McGraw Hill Publishing Co. Ltd. New Delhi.

Lesson, S. and J.D. Summers. 1990. Production and Carcass Characteristics of The Chicken. Poultry science.59:786-798.

Soeharsono. 1999. Prospek Penggunaan Probiotika sebagai Pengganti Antibiotika untuk Ternak. Wacana Ilmu Pengetahuan Teknologi dan Seni Tahun Akademik 1999-2000. Universitas Padjajaran.

Sudha, 2011. Streptomyces cavourensis sp. SU 3 Nov., A Novel Marine Streptomycetes Isolated from A Sea Shore Sediment in Chennai. Advanced Biotech. 11(05): 32-36.

Tofari, M. 2006. Pengaruh Penggunaan Limbah Destilasi Minuman beralkohol dalam Ransum terhadap Presentase Karkas Ayam Broiler. Fakultas Peternakan Universitas Diponegoro, Semarang.

Wahju, J. 1985. Ilmu Nutrisi Unggas. GajahMada University Press. Yogyakarta.

Witantra. 2011. Pengaruh Pemberian Lisin dan Metionin Terhadap Persentase Karkas dan Lemak Abdominal pada AyamPedaging Asal Induk Bibit Mudadan Induk Bibit Tua. Artikel Ilmiah. Universitas Airlangga. Surabaya. 